\title{
Examining the ecosystem service of nutrient removal in a coastal watershed
}

\author{
Chelsea E. Berg a, Madeleine M. Mineau ${ }^{\mathrm{b}}$, Shannon H. Rogers ${ }^{\mathrm{a}, *}$ \\ ${ }^{a}$ Center for the Environment, Plymouth State University, United States \\ ${ }^{\mathrm{b}}$ Earth Systems Research Center, University of New Hampshire, Durham, NH, USA
}

\section{A R T I C L E I N F O}

\section{Article history:}

Received 30 April 2015

Received in revised form

17 June 2016

Accepted 21 June 2016

Available online 27 July 2016

Keywords:

Ecosystem service valuation

Nutrient retention

InVEST

Great Bay

Avoided cost analysis

FrAMES

\begin{abstract}
A B S T R A C T
Globally, managers are trying to prevent or halt the eutrophication of valuable estuaries and bays by reducing nutrient inputs, but justifying the cost of conservation or processing facility upgrades often proves challenging. We focus on a coastal watershed in Maine and New Hampshire struggling with the financial burdens of nitrogen pollution mandates due to the eutrophication of the Great Bay estuary. After creating two future watershed land cover scenarios comparing plausible extremes, we ran them through two models, the Natural Capital Project's InVEST (Integrated Valuation of Ecosystem Services and Tradeoffs) and a detailed hydrologic and biogeochemical river network model FrAMES (Framework for Aquatic Modeling of the Earth System). Through this work, we both evaluated and valued the ecosystem service of nitrogen retention. We find that both models provide numerical arguments for conservation efforts, and decision makers would benefit from using either an ecosystem services model or a biogeochemical model when dealing with complex issues like nutrient overenrichment. According to both our modeling results, modest watershed conservation efforts as defined by our expert stakeholders, ie: protecting wetlands and forests, could reduce the amount of total nitrogen entering the Great Bay estuary in the range of 3-28 metric tons per year.
\end{abstract}

(c) 2016 The Authors. Published by Elsevier B.V. This is an open access article under the CC BY-NC-ND license (http://creativecommons.org/licenses/by-nc-nd/4.0/).

\section{Introduction}

Human communities, on a local and global scale, depend on diverse natural systems for a variety of goods and services, also known as ecosystem services (ES) (Jacobs et al., 2013; Millennium Ecosystem Assessment, 2003). There is an international movement, ie: Intergovernmental Platform on Biodiversity and Ecosystem Services or Convention on Biological Diversity's Aichi targets, to incorporate ES into policies in order to holistically address human, economic, and environmental well-being (Neßhöver et al., 2013; President's Council of Advisors on Science and Technology, 2011; Russi et al., 2013). Due to this movement, academics and others have created a host of new decision-support tools to make quantifying ES easier for decision makers, and some tools have a built-in economic analysis function (Bagstad et al., 2013; Kareiva et al., 2011; Villa et al., 2014). The goal for the majority of ES tools is place-specific analysis to inform planning options (Grêt-Regamey et al., 2014), which can also potentially be accomplished with other tools that are not explicitly labeled as ES tools (Vigerstol and Aukema, 2011). Researchers and decision makers are

\footnotetext{
*Correspondence to: Center for the Environment, Plymouth State University, MSC 6317 High Street, Plymouth, NH 03264, United States.

E-mail address: shrogers@plymouth.edu (S.H. Rogers).
}

looking for accessible methods with which to better understand and value ES. For this work, we chose one ES model and one model without the ES label: InVEST and FrAMES.

The Natural Capital Project's InVEST (Integrated Valuation of Environmental Services and Tradeoffs) modeling suite contains a spatial model focused on understanding the effect of land management trends by focusing on nutrient retention, specifically nitrogen $(\mathrm{N})$ or phosphorus, in a specific geographic region (Kareiva et al., 2011). Using data on land use and land cover (LULC), nonpoint sources, precipitation, soil types, and slopes, InVEST predicts the annual biophysical contribution of landscapes in total nitrogen (TN) and then calculates a dollar value for the ES of N or phosphorus retention. Although there are an array of ES models available, we decided to use InVEST as the representative ES model because of its capacity to model $\mathrm{N}$, the built-in economic evaluation, the published examples of other decision making uses, and its free "off the shelf" availability (Bassi et al., 2009; Hulse et al., 2004; Swetnam et al., 2011). As it is often recommended to natural resource decision makers as a viable option for gaining additional knowledge, it's touted user-friendliness was also attractive to us. Since this decision Bagstad et al. have compared or described 17 ES tools in an effort to discover ease of use (2013), however InVEST is still a recommended option for many, and we see strong value in investigating this tool. 


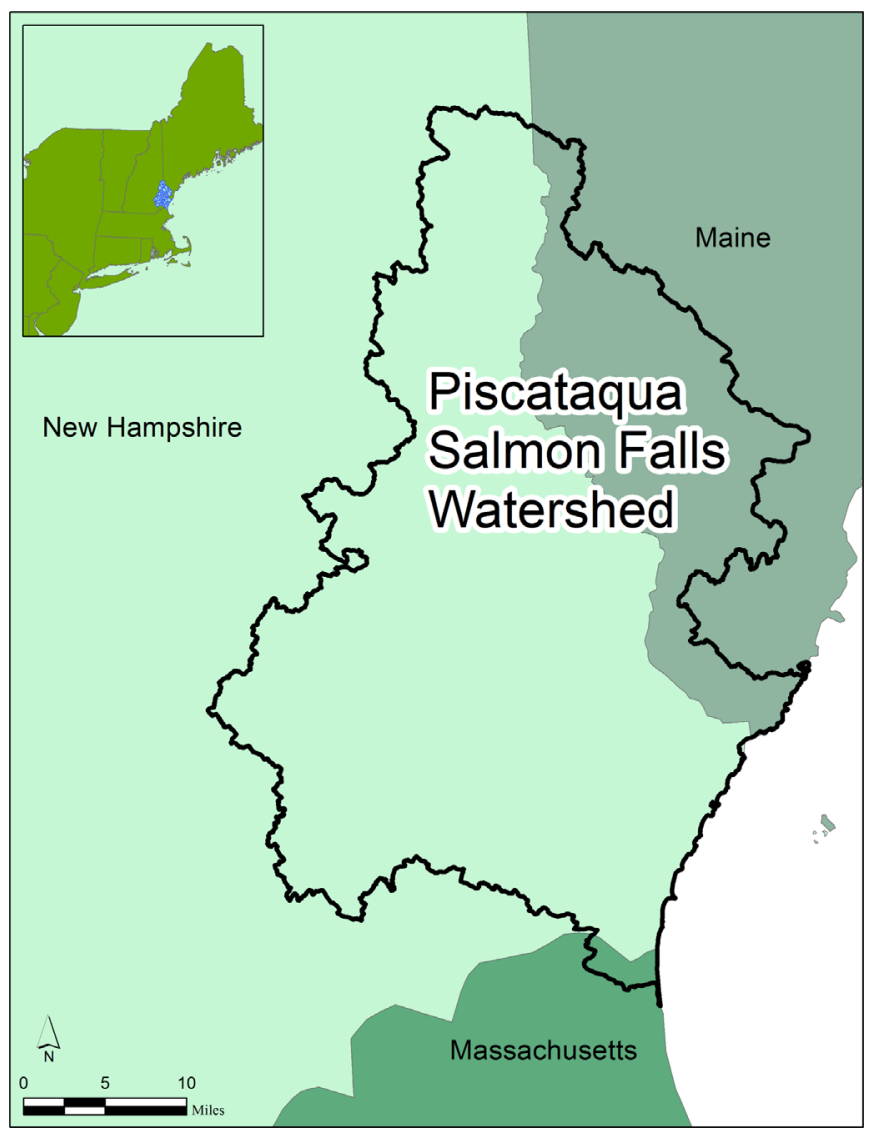

Fig. 1. Study location, the Piscataqua-Salmon Falls watershed (PSFW), in spatial context.

Our non-ES labeled model, FrAMES (Framework for Aquatic Modeling of the Earth System), also spatially evaluates N, specifically the loading to river networks and in-stream processing of dissolved inorganic nitrogen (DIN). FrAMES is a spatially distributed hydrology and biogeochemical river network model that was developed at the University of New Hampshire (UNH) and locally adapted to New England watersheds. Although it is not described with ES language, the model does provide information on aquatic nitrogen removal, which is an ES, at varying spatial and temporal scales. It also accounts for seasonal variation and instream DIN dynamics. It could be helpful for local decision makers if presented with ES language (Smart et al., 2012).

We used the two different models for the Piscataqua-Salmon Falls watershed (PSFW) that flows into the Great Bay Estuary (GBE) on the coast of New Hampshire and Maine (Fig. 1). Water body managers around the world are dealing with the challenge of nutrient overenrichment related to population increase. In that way, the PSFW is relevant to nutrient impaired coastal water bodies all over the Globe struggling with the impacts of increasing human populations in sensitive coastal areas. Within the PSFW, the GBE, along with the majority of the Northeast's estuaries influenced from the flow of nutrients downstream, is deteriorating into a state of anthropogenic nutrient overenrichment called eutrophication (Lee et al., 2004; Piscataqua Region Estuaries Partnership, 2013; Vitousek et al., 1997). With increased population density driving land cover and land use changes, GBE is one of the six "hot spots" of poor water quality in New England (Office of Research and Development and Office of Water, 2012). Like most coupled human and natural systems, the primary cause of this decline is debated due to imperfectly understood interactions and drivers of change, but studies point to increased levels of nitrogen
(N) as the main driver (Howarth, 2008; Liu et al., 2007; Odell et al., 2006).

Human activities increase the flow of $\mathrm{N}$ from land through fertilizer application, air pollution, and point sources like wastewater treatment plants (Driscoll et al., 2003; Vitousek et al., 1997). As shown in Fig. 2, eighteen publicly owned treatment works (POTWs), point sources of $\mathrm{N}$ from human wastewater, release about twenty million gallons a day of processed effluent into the GBE, its tributaries, or into the tidally relevant waters (Spalding, 2012). Upgrading the POTWs to the limits of technology represents an immense potential financial cost to local ratepayers, estimated at 354 million dollars (Kessler, 2010). Several organizations and community members are interested in approaching the issue from an alternative perspective, specifically land conservation (Rogers et al., 2014; Vanasse Hangen Brustlin, Inc., 2014).

Land conservation has the potential to remove $\mathrm{N}$ from the Great Bay because natural landscapes retain nutrients. For example, New York City, Boston, and other international areas have shown that allocating resources towards conservation efforts or green infrastructure can significantly reduce nutrient levels and provide a cost savings over wastewater treatment or water filtration plant upgrades because natural landscapes retain nutrients (Daily and Ellison, 2002, pp. 61-85; Foran et al., 2000; Grolleau and McCann, 2012; National Research Council, 2005). In other cases, integrated management plans provide the most effective strategy to reduce $\mathrm{N}$ (Driscoll et al., 2003; Lowrance et al., 1997; Mitsch et al., 2001). Talberth et al. (2013) tested avoided cost methods in Portland, Maine, for the Sebago Lake Watershed by running six future landscape scenarios through a mapping software to look at infrastructure options and costs over 20 years under different discount rates. By investing in green infrastructure such as riparian buffers, culvert upgrades, reforestation, and conservation easements, Portland found that they could save up to $71 \%$ of the cost of a new drinking water filtration plant. In a similar effort, we wanted to evaluate the potential of alternative management, specifically conservation easements and reforestation, to avoid or offset some of the costs of proposed POTW upgrades in the PSFW.

In order to accomplish this goal, we needed to first know the range of potential $\mathrm{N}$ loading and retention efficiencies from both extremes of conservation and development futures. Future scenario generation is commonly used in the ecosystem services field (Alcamo, 2008; Cook et al., 2014). As described in detail in a previous publication, we queried a variety of expert stakeholders representing various sectors, build future land cover scenarios, and simulated the impacts of both conservation efforts and increased development on N loads from each tributary (Berg et al., 2015). Again, the ultimate goal of this study was to investigate the amount of nitrogen removed and costs avoided of non-point source $\mathrm{N}$ management compared to point source management using two stakeholder-driven future land cover scenarios. We hypothesized that like the Sebago example, an alternative management plan would allow the Great Bay municipalities to avoid part of the proposed cost associated with upgrading 18 POTWs to the best available technology by reducing the non-point source pollution load through conservation.

\section{Methods}

\subsection{Scenario generation}

In order to evaluate potential future $\mathrm{N}$ loads to the GBE, we needed to decide how LULC change could occur over our study area. Specifically, we were interested in discovering the full range of $\mathrm{N}$ retention between a very conservation focused future vs a development focused future. As part of the scenario generation, 


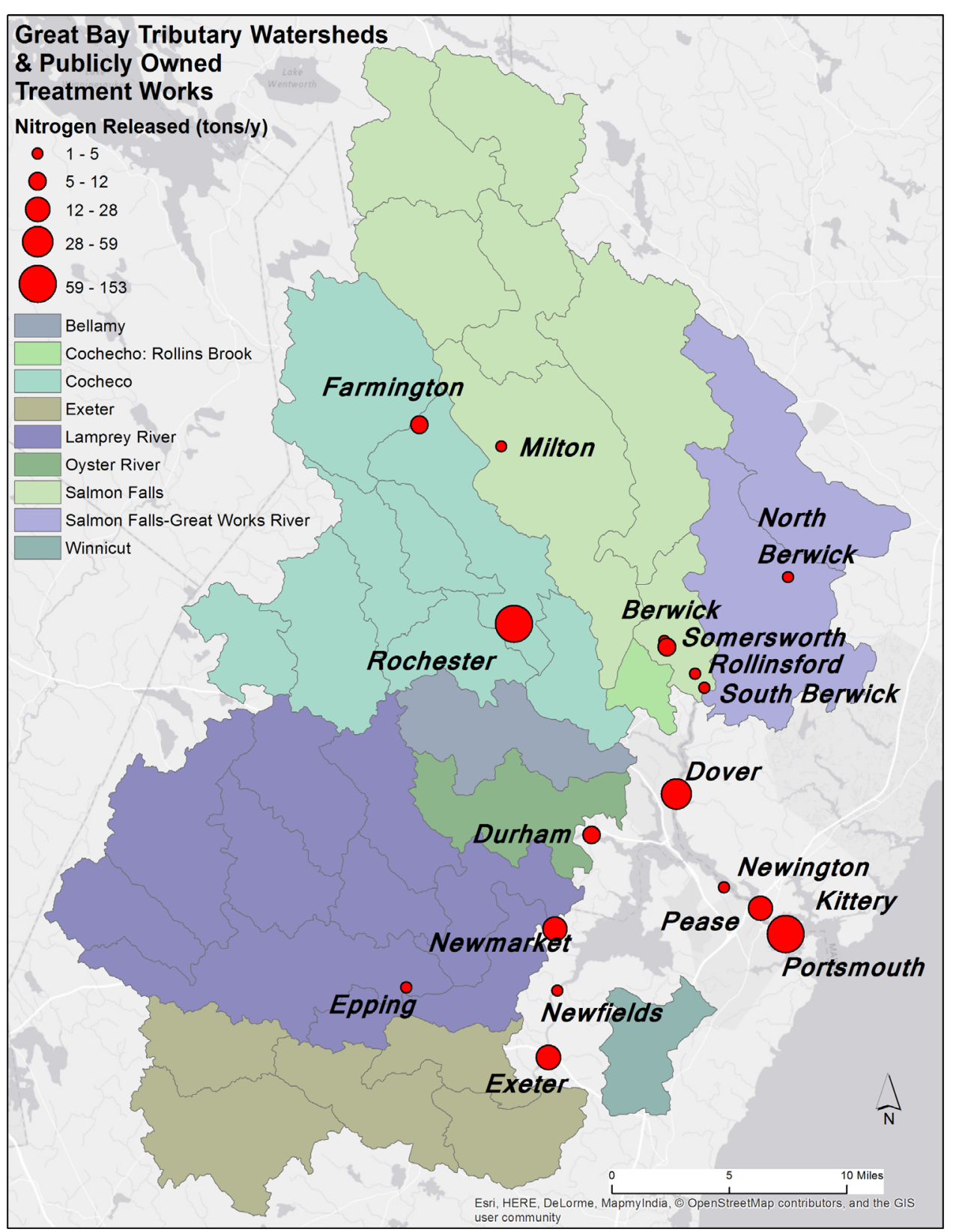

Fig. 2. $\mathrm{N}$ point sources (POTWs) and subwatersheds in the study area. The dot size reflects the amount of $\mathrm{N}$ released per year.

we queried local expert stakeholders representing public, private, and non-profit sectors, with 16 out of 18 interested stakeholders completing the questionnaire that helped us determine drivers and expected magnitude of land cover change over a 10 year period. As further described with full questionnaire used in Berg et al. (2015), we created scenarios of conservation and development trajectories using the InVEST Scenario Generator Tool version 3.1.0. to use as input into both models to produce both the value of $\mathrm{N}$ retained in both scenarios and the amount of $\mathrm{N}$ exported (Fig. 3).

\subsection{Running InVEST}

We gathered and processed the data layers that InVEST requires and are further explained in the User's Guide: LULC, precipitation, a digital elevation model, soil depth, evapotranspiration, watershed delineations, plant available water content, and

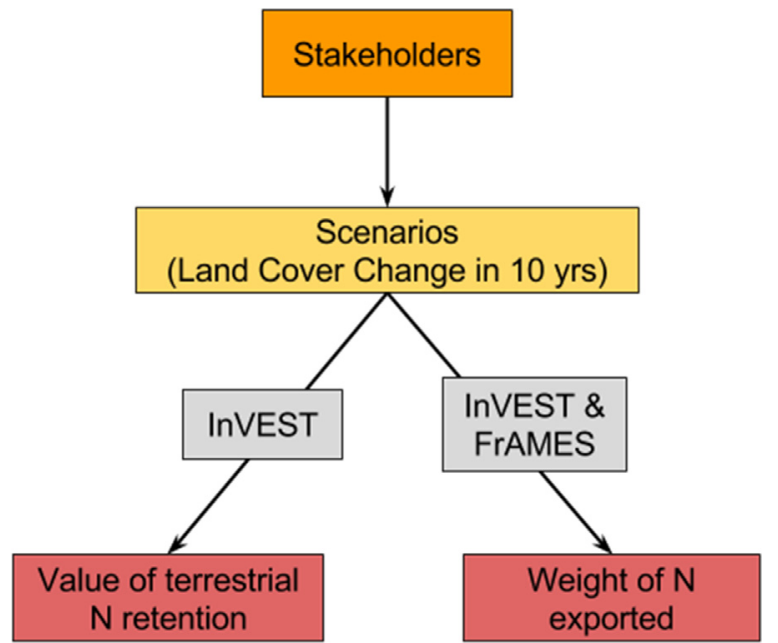

Fig. 3. Conceptual map of the methodology employed to discover alternative management potential for the PSFW. 
Table 1

The 7 land cover types and their corresponding $\mathrm{N}$ loading and removal allocations used to create the biophysical table for InVEST as derived from the literature.

\begin{tabular}{|c|c|c|c|c|}
\hline Land Cover & $\begin{array}{l}\text { TN load }(\mathrm{kg} / \mathrm{ha} / \mathrm{yr}) \\
\text { Efficiency Rate }(0-1)\end{array}$ & Sources & Published Range & Sources \\
\hline Urban & $30.5 ; 0$ & Line et al. 2002 & $1.6-38.5$ & Beaulac and Reckhow, 1982; Rast and Lee 1978; Loehr et al. 1989 \\
\hline Suburban & $23.9 ; 0$ & Line et al. 2002 & 5-23.9 & $\begin{array}{l}\text { Bales et al., 1993; Hartigan et al. 1983; USEPA, 1983; Line et al. } \\
\text { 2002; Loehr 1974; }\end{array}$ \\
\hline Barren Land & $12.4 ; 0$ & Dodd et al. 1992 & $0.5-12.4$ & Dodd et al., 1992; Loehr 1974; \\
\hline Forest & $11.4 ; 0.6$ & $\begin{array}{l}\text { Line et al. 2002; Breemen et al. } \\
2002\end{array}$ & $1.6-11.4$ & $\begin{array}{l}\text { Dodd et al. 1992; Beaulac and Reckhow, 1982; Line et al. 2002; } \\
\text { Rast and Lee 1978; Loehr et al. 1989; }\end{array}$ \\
\hline Open Fields & $8.6 ; 0.3$ & $\begin{array}{l}\text { Reckhow et al. 1980; Howarth } \\
1996\end{array}$ & $1.48-30.8$ & Beaulac and Reckhow, 1982; Line et al. 2002 \\
\hline Cultivated Crops & $53.5 ; 0.1$ & $\begin{array}{l}\text { Wollheim Curve; Breemen et al., } \\
2002\end{array}$ & $2.1-79.6$ & $\begin{array}{l}\text { Beaulac and Reckhow, 1982; Wollheim et al., 2008; Rast and Lee } \\
\text { 1978; Loehr et al. 1989; }\end{array}$ \\
\hline Wetland & $3.8 ; 0.6$ & $\begin{array}{l}\text { Dodd et al., 1992; Saunders and } \\
\text { Kalff, } 2001\end{array}$ & $0.69-3.8$ & Dodd et al., 1992 \\
\hline
\end{tabular}

hydrologic seasonality (Donohue et al., 2012; Jin et al., 2013; Lehner et al., 2006; Liang and Liu, 2014; PRISM Climate Group, n. d.; Sharp et al., 2014; Soil Survey Staff, 2013; Trabucco and Zomer, 2009; United States Geological Survey, 2013; Xu et al., 2013, p. Fig. 3; Zhang et al., 2004). When possible, we used the same input data sources as FrAMES. ${ }^{1}$ We also created the required biophysical table that contains critical information regarding how $\mathrm{N}$ interacts with each land cover type. We completed a literature review to make these decisions, and we chose the higher end of $\mathrm{N}$ levels in the literature when optimizing the model because those were more inline with the measured data we had on the system (Table 1).

\subsection{Running FrAMES}

FrAMES has similar data requirements as InVEST but at a much more detailed scale. For example, the soil data incorporated impervious surfaces, percent silt to clay, and the The National Land Cover Dataset (NLCD) to calculate the available water capacity. The National Land Cover Dataset (NLCD) 2006 was translated into percent human land use and percent agriculture per grid cell based upon grouping the land cover classifications. FrAMES used the percent developed land use/agriculture and daily precipitation information to obtain the concentration of dissolved inorganic nitrogen (DIN) entering the stream, and sequentially modeled routing and biogeochemical processing of DIN within the river network. The spatial resolution can be set to various sizes, but our analysis used grid cells of approximately $500 \mathrm{~m}$ to a side. For more detailed information regarding the model parameters and loading relationships see Wollheim et al. (2008).

\subsection{Evaluating model parameters and goodness of fit}

As with all models, there is inherent uncertainty because they do not perfectly represent reality. In order to know how well each model represented the study area, we compared the results to observed data from nonpoint sources from the Piscataqua Region Estuaries Partnership (PREP, 2009). We compared FrAMES' results,

\footnotetext{
${ }^{1}$ The tidal portions of our study area prove challenging when modeling due to the complexity of physical and spatial variability (Kinney and Valiela, 2011). For instance, the GBE represents 21 square miles of tidal waters indirectly linked to the Atlantic Ocean by nine miles of the Piscataqua River (Trowbridge et al., 2014). Thus, the tide reverses water flow direction and raises and lowers the Great Bay substantially twice daily. These tidal influences also reach the tributaries, so we trimmed each watershed boundary to remove the tidal draining portions of the land mass based on topographically driven hydrology. Although this eliminates some important developed areas such as the city of Portsmouth, $\mathrm{NH}$ from our evaluation, we took this step because FrAMES does not model flow direction reversal.
}

Table 2

The ratio relationships used to convert FrAMES output to TN.

\begin{tabular}{ll}
\hline Tributary & \% DIN \\
\hline Winnicut & 28.7 \\
Exeter & 28.9 \\
Lamprey & 32.6 \\
Oyster & 37.0 \\
Bellamy & 24.4 \\
Cocheco & 66.8 \\
Salmon Falls & 33.6 \\
Great Works & 31.7 \\
\hline
\end{tabular}

the average DIN output from a five year period of 2009-2013, to the DIN 2009-2011 loads from PREP (2009, Table NUT1-3). Based largely on the work of Legates and Mccabe (1999), Fox (1981), Krause et al. (2005), and Willmott (1982), we decided to avoid Pearson's correlation ( $r$ ) and the coefficient of determination (r2) as model evaluative parameters; instead, we relied upon two estimates of average error: mean absolute error (MAE) and root mean square error (RMSE). The level of difference between RMSE and MAE should indicate the extent of variance from modeled to observed. Although we would like to use coefficient of efficiency (Nash-Sutcliffe) or index of agreement, InVEST does not produce a time series. Thus, we relied predominately upon RMSE and MAE, as these parameters do not require a time series and are easily conceptualized since they are reported in the same units as the model results being tested.

Using the analysis published by the Piscataqua Region Estuaries Partnership (PREP, 2012), we converted FrAMES DIN output to TN by ratio relationship (DIN:TN) per tributary as sampled by PREP (Table 2). We also added the point source TN contributions reported by PREP into InVEST's output of TN for each scenario. In order to determine an avoided $\mathrm{N}$ contribution achieved by reducing land development, we subtracted the TN exported under the increased conservation scenario from the TN exported under the increased development scenario for both FrAMES and InVEST.

\subsection{Economic analysis}

InVEST requires an economic valuation input table to calculate the avoided cost of nitrogen removal. ${ }^{2}$ We calculated the value of $\mathrm{N}$ retained using three approximations of value: benefits transfer from Jenkins et al. (2010); average and median marginal

\footnotetext{
${ }^{2}$ The economic feature of the InVEST Nutrient Retention model is optional, but it calculates the value of $\mathrm{N}$ retention per subwatershed from the perspective of avoided treatment costs using this calculation.
} 


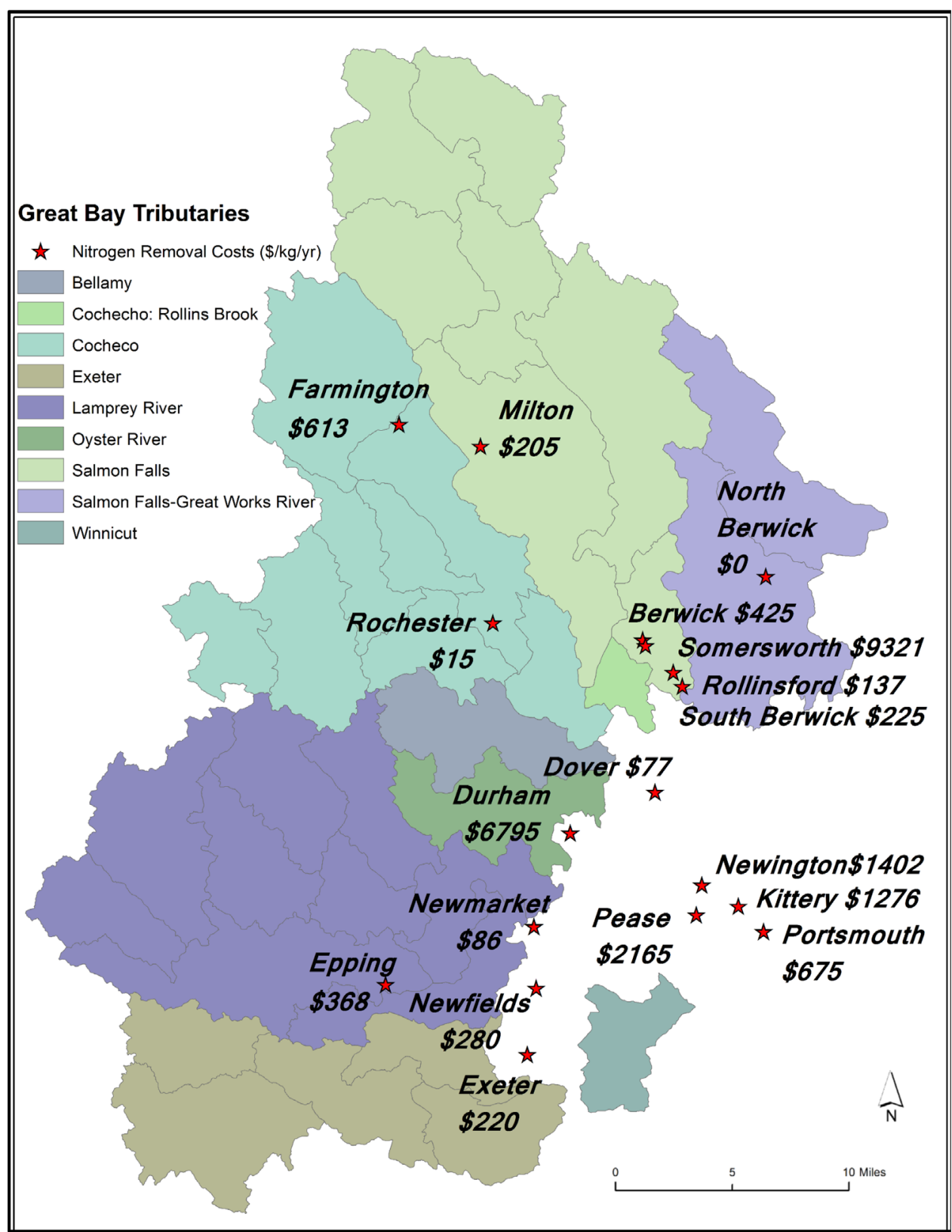

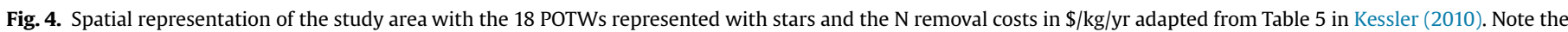
variation in cost from $\$ 15$ to $\$ 9321$ which created difficulty in determining marginal abatement costs.

abatement costs of the 18 POTWs (Kessler, 2010); spatially allocated marginal abatement costs by tributary (Kessler, 2010). We included the benefits transfer because it represents an actual range of the cost of marginal trade for nitrogen reduction credits that could potentially be devised for our study region. Furthermore, we opted to run both the median and mean for the POTW cost per kg to demonstrate the difficulty in applying one value for the entire watershed. InVEST allows values of $\mathrm{N}$ retention to differ

(footnote continued)

$w p \_$Value $_{w}=\operatorname{cost}(p)^{*}$ retained $_{w} * \sum_{t=0}^{T-1} \frac{1}{(1+r)^{t}}$

as described on page 133 of the InVEST User Manual 3.0.1. : the value of retention for subwatershed = annual treatment cost $(\$ / \mathrm{kg}){ }^{*} \mathrm{~N}$ retained ${ }^{*}$ sum of the time span being considered using the appropriate discount rate as given by the user. between subwatersheds, and we used this capability to conduct a tributary-specific analysis of value. Because the spatial distribution of POTWs and cost was so variable (Fig. 4), we had to create rules to assign these values. ${ }^{3}$ We took the median of required upgrades along each tributary; for the two tributaries with no associated POTWs, we took the value from a town within the watershed boundary with a POTW (Table 5). We used discount rates of one, three, and five percent, which is a common range of discount rates in present value calculations, to represent various levels of the time preference for money in the net present value calculations of the avoided costs over a 10 year period. This generated three different estimates of cost of $\mathrm{N}$ per kg updated to 2015 dollars using

${ }^{3}$ Some POTWs were not included under these rules, specifically Pease, Newington, Kittery, and Portsmouth. With a model that could represent tidal flow, they would be included. 
the CPI Inflation Calculator over the 10 year period of our stakeholder driven scenarios (BLS, 2015).

The economic feature of the InVEST Nutrient Retention model is optional, but it calculates the value of $\mathrm{N}$ retention per subwatershed from the perspective of avoided treatment costs using this calculation, as described in the user manual: the value of retention for subwatershed $=$ annual treatment cost $(\$ / \mathrm{kg})^{*} \mathrm{~N}$ retained * sum of the time span being considered using the appropriate discount rate as given by the user. See equation above and on page 133 of the InVEST User Manual.

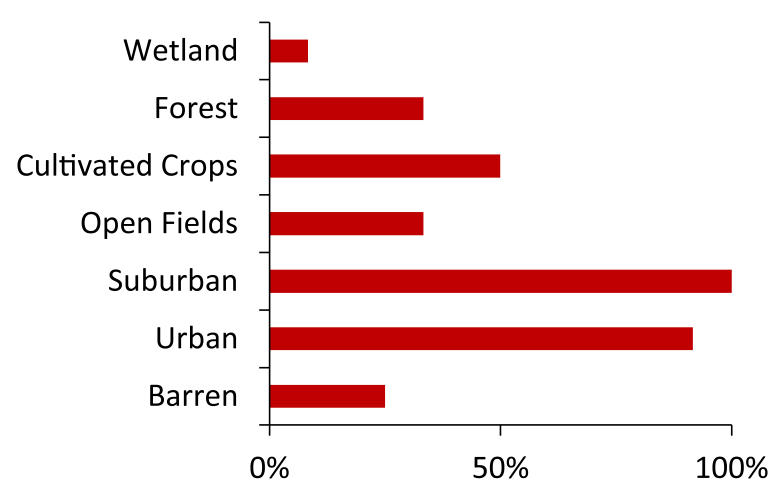

Fig. 5. Visual representation of our expert stakeholders' advice regarding land cover likelihood of increase under a development scenario $(n=13)$.
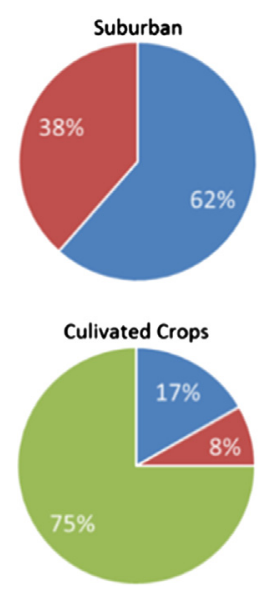

Fig. 6. Expert Stakeholder's ranking of land cover change potential in the study area for $2015-2025(\mathrm{n}=12)$.

\section{Results}

\subsection{Land cover scenarios}

For the Increased Development Scenario, the majority of our experts predict that cultivated crops, suburban, and urban land covers will increase by $7 \%$ over the next ten years (Fig. 5). When asked to rank urban, suburban, cultivated crops, and open fields, experts chose suburban areas as most likely to increase (Fig. 6) and confirmed the previous question's results that development in the study area will increase land cover in (1) suburban, (2) urban, and (3) cultivated crops. They indicated that development would still occur under a conservation scenario but at 3\% total. They also noted that while conservation efforts have the potential to increase by $15 \%$ of the watershed, conservation priorities lean heavily towards more pristine land parcels and less towards remediation efforts. Translating this into land cover changes, conservation will mostly protect existing forests and wetlands while creating potentially $1 \%$ more forest. All of the results of the stakeholder driven scenarios, including the questionnaire we used, are available in an open access peer reviewed publication: http://www.sciencedirect.com/science/article/pii/S00163287 15001639.

\subsection{Comparison of model outputs}

In comparison to the sampled N levels (Piscataqua Region Estuaries Partnership, 2012), InVEST consistently underestimated the TN loads to the GBE (Fig. 7); FrAMES produces a variety of results as the Lamprey was underestimated while the others range from 1.2 to 2 times the DIN estimate from PREP (Fig. 7). When comparing goodness-of-fit statistics between observed and modeled $\mathrm{N}$ loads, neither model dramatically out performs the other

\section{Table 3}

Various descriptive statistics that indicate the effectiveness of the programs to model the observed conditions. MAE and RMSE describe the average difference in the same units as the measurements (metric tons/yr). The MAE is less sensitive to extreme values than RMSE. Overall, the models perform similarly, with MAE favoring InVEST and RMSE favoring FrAMES.

\begin{tabular}{lllll}
\hline Statistic & Observed_DIN & FrAMES_DIN & Observed_TN & InVEST_TN \\
\hline Mean & 45 & 57 & 83 & 70 \\
Standard & 59 & 73 & 62 & 52 \\
$\quad$ Deviation & & & & 12.4 \\
MAE & & 13.7 & 18.2 \\
RMSE & & 17.2 & \\
\hline
\end{tabular}
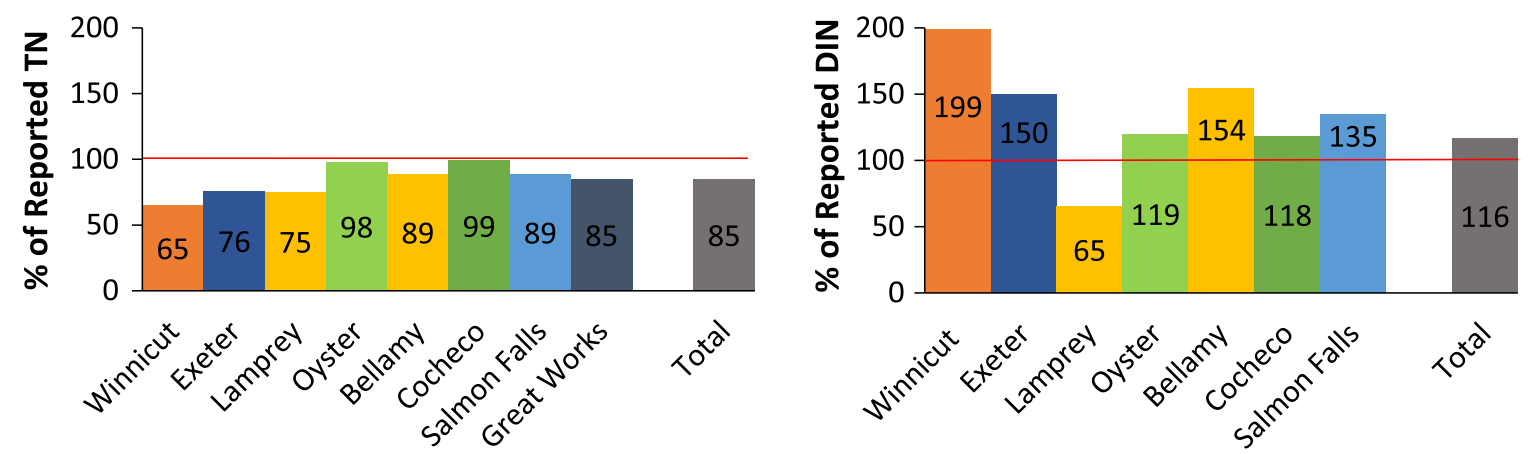

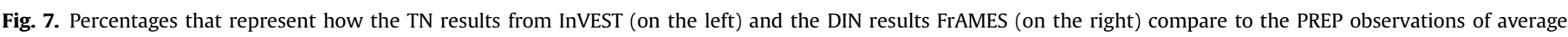
annual load of TN and DIN from each tributary. 


\section{Table 4}

Results (in millions of dollars) from InVEST that measure the value of $\mathrm{N}$ retention over 10 year scenarios at discount rates of 1,3 , and 5 . Values shown are the difference between future scenarios of increased conservation and increased development using place-specific values from a NH DES report (Kessler, 2010). For an expanded table, contact lead author.

\begin{tabular}{lccc}
\hline Discount Rate & $1 \%$ & $3 \%$ & $5 \%$ \\
\hline Mean Marginal Value $(\$ 1538 / \mathrm{kg})$ & 46.4 & 43.1 & 40.1 \\
Median Marginal Value $(\$ 396 / \mathrm{kg})$ & 11.9 & 11.1 & 10.3 \\
Break-out by Subwatershed (see Table 5) & 18.6 & 17.3 & 16.1 \\
\hline
\end{tabular}

Table 5

The subwatershed breakout calculations of $\mathrm{N}$ retention valuation of the terrestrial ecosystem used the figures shown in this table. These were devised spatially by tributary using the rules mentioned in Section 2.4. Note that the values are in 2015 dollars.

\begin{tabular}{lll}
\hline Tributary Name & $\begin{array}{l}\text { Value of N retention } \\
(\$ / \mathrm{kg})\end{array}$ & POTWs Used \\
\hline Winnicut & 726 & Portsmouth \\
Great Works & 242 & South Berwick \\
Salmon Falls & 339 & Milton, Somerworth, Berwick, \\
& & Rollinsford \\
Oyster & 7314 & Durham \\
Bellamy & 82 & Dover \\
Lamprey & 244 & Epping, Newmarket \\
Exeter & 269 & Newfields, Exeter \\
Cocheco & 338 & Rochester, Farmington \\
\hline
\end{tabular}

(Table 3). ${ }^{4}$ We do not report variation about the mean because InVEST only reports one set of annual results when using the recommended input data. FrAMES time series provides information on daily, seasonal, and annual variation.

\subsection{Value of $N$ retained in the terrestrial ecosystem}

\subsubsection{Benefits transfer method}

Using the range of annualized value of $\mathrm{N}$ mitigation service as reported by Jenkins et al. (2010), ${ }^{5}$ InVEST suggests that the net present value of nutrient retention in the PSFW under increased conservation over ten years will be worth $\$ 645,312$ to $\$ 3.5$ million more than under the increased development scenario. The range represents varying values of $\mathrm{N}$ weights and discount values of $1 \%$, $3 \%$, and $5 \%$.

\subsubsection{Local value method}

Using the place-specific marginal social cost of abatement by upgrading to best technology as reported by the draft New Hampshire Department of Environmental Services' wastewater engineering report on upgrade costs, we find that the ES value of $\mathrm{N}$ retention under conservation ranges from $\$ 10.3$ to $\$ 46.4$ million (Table 4).

\subsection{Comparison of total nitrogen exports}

Holding point sources constant, FrAMES predicts that an average of 28.1 metric tons of TN will be added to the system per year under an increased development scenario. InVEST predicts that

\footnotetext{
${ }^{4}$ Each model has inherent uncertainties, and we encourage those interested to see the lengthy model documentation of each using the citations provided throughout.

${ }^{5}$ We updated Table 2 of Jenkins et al. (2010) to represent 2015 dollars. The annualized value of $\mathrm{N}$ was based upon costs of marginal $\mathrm{N}$ credits from Ribaudo et al. (2005). These values ranged from $\$ 24.77$ to $\$ 115.16$ per $\mathrm{kg}$, much lower than our place-specific values.
}

3.1 metric tons of TN will be added to the system per year under development. Based upon modeled to observed comparisons, we suggest that InVEST's $3.1 \mathrm{t}$ TN/yr is an underestimate and FrAMES' $28.1 \mathrm{t} \mathrm{TN} / \mathrm{yr}$ is an overestimate. Thus, these results present the full range of potential avoided TN exports through conservation.

\subsection{Potential avoided cost}

If Epping's POTW upgrades to generate $3 \mathrm{mg} / \mathrm{l} \mathrm{TN}$ effluent, [DES estimates] it would remove an estimated additional 2.99 metric tons TN /yr. A conservative estimate of the effect of realistic land conservation efforts across the watershed would provide analogous benefits to the Epping POTW upgrading to the best available technology. The FrAMES estimate of $28.1 \mathrm{t} \mathrm{TN} / \mathrm{yr}$ is comparable to upgrading the Newmarket POTW, which will keep $26.5 \mathrm{t} \mathrm{TN/yr}$ from entering the GBE.

\section{Discussion/conclusions}

First, our analysis contributes to the growing knowledge and attempts to understand the GBE, a cherished resource. Instead of discussing potential savings using dollars, we provide situational insight by indicating equivalencies between upgrading specific POTWs and conservation efforts. Upgrading all 18 POTWs is estimated to remove roughly $281 \mathrm{t} / \mathrm{yr}$ (Kessler, 2010), and even under the high conservation removal estimate of $28.1 \mathrm{t} / \mathrm{yr}$, point source reductions are needed. Although there is much debate regarding contributing factors, managing the POTWs is most direct management option for N. Driscoll et al. (2003) found that in eight estuaries in the northeastern United States, POTW effluent is the greatest source of anthropogenic $\mathrm{N}$ from the watersheds and the most effective $\mathrm{N}$ source to control under a single option management style. However, the conservation strategy could avoid the cost of upgrading wastewater infrastructure on the order of 10-46 million dollars over 10 years.

Second, comparing these two models provides useful data to academics, decision makers, and policy advisors (Vigerstol and Aukema, 2011). Although mapping and modeling tools provide helpful information, these tools have limitations and many lack rigorous uncertainty analyses (Hamel and Guswa, 2015). There is a vast array of ES tools for regulators to use, and we have detailed the process, data requirements, and comparative accuracy of one InVEST tool. The numerical results of our work with InVEST were highly dependent upon what filtering efficiencies and loading rates we assigned each land cover in line with the sensitivity analyses conducted by Hamel (2014). Other work with InVEST emphasized that numerical results should only be considered in relation to each other at the subwatershed scale instead of taken as absolute (Goldstein et al., 2012). The user has incredible control of model inputs, but this places the burden on the user to find locally-relevant information on $\mathrm{N}$ loading and efficiency rates, which we found tedious. For FrAMES, users would need to contact an academic group to ask for model results. This limitation indicates that FrAMES and other biogeochemical models like it have barriers to use that InVEST does not share. If decision makers partnered with local academic institutions, they could adapt other models, like FRAMES, to produce ES relevant results without allocating resources to learning modeling software like InVEST. If decision makers did have the resources and time to learn the InVEST tool and locate the needed information, we find the modeling results to be helpful and relevant.

InVEST has many affable qualities, but the ranking of more than one ES at the spatial scale is the most positive aspect of this tool. Although capacity to field multiple criteria and analyses is beneficial, it is also a limitation. For our situation, we only relied upon 
the nutrient removal model. Without the comparison between models, the usability of InVEST declines. For example, a project in Belize allowed for multiple objectives and impacted ES to be mapped and compared (Ruckelshaus et al., 2015). Although there are various other components of the Great Bay issue, $\mathrm{N}$ retention is the most pressing ES valuation, and conducting an avoided cost requires a model that is more comfortable with the goal of precise quantification. If there were competing ES, InVEST would have provided more insight into the broad patterns of spatial variation (Bhagabati et al., 2014). Although InVEST is independently available, we find that it would be a better use of decision makers' resources to contract with academic or consulting groups in order to receive the best approximation of one or two ES like nutrient retention using other models that may not have the ES label.

Future work could focus on determining the costs of conservation of LULC over the ten year projection. Then, we could compare the costs of conservation to the costs of POTW upgrades to discern the avoided cost potential of conservation in the PSFW. This watershed scale perspective proves challenging to support, though, because $\mathrm{N}$ management at the watershed scale has both spatial awareness and social capital barriers in the PSFW (Washburn, 2013). Also, future analysis should focus more on modeling the potential impacts of green infrastructure improvements that do not change the LULC classification but impact $\mathrm{N}$ retention. We suggest looking at municipal level improvements as Roy et al. (2014) found that decentralized approaches to stormwater management on private property did not produce noticeable results in streams.

\section{Acknowledgments}

Funding for this project was provided by NH EPSCoR with support from the National Science Foundation's Research Infrastructure Improvement Award \# EPS 1101245. Numerous people deserve recognition for their part in this work, but without the expert stakeholders (you know who you are!), the scenarios would not exist. We thank the entire Ecosystems \& Society Team from NH EPSCoR, with special thanks to Mark Green, David Lutz, Mark Borsuk, Georgia Mavrommati, Richard B. Howarth, Rob Stewart, Stanley Glidden, Jennifer Bell, and Jonathon Loos for your particular insight and aid. Cameron Wake, Alexandria Thorn, Curt Grimm, Clay Mitchell, Barbara Wauchope provided helpful reference maps for the questionnaire. Robert Pruyne and the Rockingham Planning Commission supplied GIS advice and helped locate spatial data. Faculty and staff in the Center for the Environment and the Department of Environmental Science \& Policy went above and beyond in supporting this effort with special thanks to Joe Boyer and Amy Villamanga. The NatCap team, specifically Rich Sharp, Perrine Hamel, and Martin Lacayo, was extremely helpful and even updated the modeling tool based on some problems we encountered.

\section{References}

Alcamo, J., 2008. Environmental Futures: the practice of Environmental Scenario Analysis. Elsevier, Amsterdam, The Netherlands.

Bagstad, K.J., Johnson, G.W., Voigt, B., Villa, F., 2013. Spatial dynamics of ecosystem service flows: a comprehensive approach to quantifying actual services. Ecosyst. Serv. Spec. Issue Mapp. Model. Ecosyst. Serv. 4, 117-125. http://dx.doi.org/ 10.1016/j.ecoser.2012.07.012.

Bales, J.D., Strickland, A.G., Garrett, R.G., 1993. An interim report on flows in the lower Roanoke River, and water quality and hydrodynamics of Albemarle Sound, North Carolina, October 1989 - April 1991. U.S. Geological Survey, Raleigh, NC.

Bassi, A.M., Harrisson, J., Mistry, R.S., 2009. Using an integrated participatory modeling approach to assess water management options and support community conversations on Maui. Sustainability 1, 1331-1348. http://dx.doi. org $/ 10.3390 /$ su1041331.

Beaulac, M.N., Reckhow, K.H., 1982. An examination of land use - nutrient export relationships. JAWRA. J. Am. Water Resour. Assoc. 18, 1013-1024. http://dx.doi. org/10.1111/j.1752-1688.1982.tb00109.x.

Berg, C.E., Rogers, S.H., Mineau, M.M., 2015. Building scenarios for ecosystem services tools: developing a methodology for efficient engagement with expert stakeholders. Futures. http://dx.doi.org/10.1016/j.futures.2015.10.014.

Bhagabati, N.K., Ricketts, T., Sulistyawan, T.B.S., Conte, M., Ennaanay, D., Hadian, O., McKenzie, E., Olwero, N., Rosenthal, A., Tallis, H., Wolny, S., 2014. Ecosystem services reinforce Sumatran tiger conservation in land use plans. Biol. Conserv. 169, 147-156. http://dx.doi.org/10.1016/j.biocon.2013.11.010.

BLS, 2015. CPI Inflation Calculator. U.S. Department of Labor- Bureau of Labor Statistics (BLS).

Breemen, N.V., Boyer, E.W., Goodale, C.L., Jaworski, N.A., Paustian, K., Seitzinger, S.P., Lajtha, K., Mayer, B., Dam, D.V., Howarth, R.W., Nadelhoffer, K.J., Eve, M., Billen, G., 2002. Where did all the nitrogen go? Fate of nitrogen inputs to large watersheds in the northeastern U.S.A. Biogeochemistry 57/58, 267-293.

Cook, C.N., Inayatullah, S., Burgman, M.A., Sutherland, W.J., Wintle, B.A., 2014. Strategic foresight: how planning for the unpredictable can improve environmental decision-making. Trends Ecol. Evol. 29 (9), 531-541.

Daily, G., Ellison, K., 2002. The New Economy of Nature: the Quest to Make Conservation Profitable. Island Press, Washington, DC.

Dodd, R.C., Cunningham, P.A., Curry, R.J., Stichter, S.J., 1992. Watershed Planning in the Albemarle Pamlico Estuarine System. Report.

Donohue, R.J., Roderick, M.L., McVicar, T.R., 2012. Roots, storms and soil pores: Incorporating key ecohydrological processes into Budyko's hydrological model. J. Hydrol. 436, 35-50.

Driscoll, C.T., Whitall, D., Aber, J., Boyer, E., Castro, M., Cronan, C., Goodale, C.L., Groffman, P., Hopkinson, C., Lambert, K., Lawrence, G., Ollinger, S., 2003. Nitrogen pollution in the northeastern United States: sources, effects, and management options. Bioscience 53, 357-374. http://dx.doi.org/10.1641/0006-3568 (2003)053[0357:NPITNU]2.0.CO;2.

Foran, J., Brosnan, T., Connor, M., Delfino, J., DePinto, J., Dickson, K., Humphrey, H., Novotny, V., Smith, R., Sobsey, M., et al., 2000. A framework for comprehensive, integrated, watershed monitoring in New York City. Environ. Monit. Assess. 62, 147-167. http://dx.doi.org/10.1023/A:1006266325869.

Fox, D.G., 1981. Judging air quality model performance: a summary for the AMS workshop on dispersion model performance. Bull. Am. Meteorol. Soc., 62.

Goldstein, J.H., Caldarone, G., Duarte, T.K., Ennaanay, D., Hannahs, N., Mendoza, G., Polasky, S., Wolny, S., Daily, G.C., 2012. Integrating ecosystem-service tradeoffs into land-use decisions. Proc. Natl. Acad. Sci. 109, 7565-7570. http://dx.doi.org/ 10.1073/pnas.1201040109.

Grêt-Regamey, A., Weibel, B., Kienast, F., Rabe, S.-E., Zulian, G., 2014. A tiered approach for mapping ecosystem services. Ecosyst. Serv. http://dx.doi.org/ 10.1016/j.ecoser.2014.10.008.

Grolleau, G., McCann, L.M.J., 2012. Designing watershed programs to pay farmers for water quality services: case studies of Munich and New York City. Ecol. Econ. 76, 87-94. http://dx.doi.org/10.1016/j.ecolecon.2012.02.006.

Hamel, P., Natural Capital Project, 2014. Uncertainty Analysis of the InVEST 3.0 Nutrient Model: Case Study of the Cape Fear Catchment, NC. Unpublished.

Hamel, P., Guswa, A.J., 2015. Uncertainty analysis of a spatially explicit annual water-balance model: case study of the Cape Fear basin, North Carolina. Hydrol Earth Syst Sci 19, 839-853. http://dx.doi.org/10.5194/hess-19-839-2015.

Hartigan, J.P., Quasebarth, T., Southerland, E., 1983. Calibration of NPS model loading factors. J. Environ. Eng. 109, 1259-1272. http://dx.doi.org/10.1061/ (ASCE)0733-9372(1983)109:6(1259).

Howarth, R.W. (Ed.), 1996. Nitrogen cycling in the North Atlantic Ocean and its watersheds. Kluwer Academic Publishers, Dordrecht; Boston.

Howarth, R.W., 2008. Coastal nitrogen pollution: a review of sources and trends globally and regionally. Harmful Algae 8, 14-20.

Hulse, D.W., Branscomb, A., Payne, S.G., 2004. Envisioning alternatives: using citizen guidance to map future land and water use. Ecol. Appl. 14, 325-341.

Jacobs, S., Dendoncker, N., Keune, H., 2013. Ecosystem Services: Global Issues. Local Practices. Elsevier.

Jenkins, W.A., Murray, B.C., Kramer, R.A., Faulkner, S.P., 2010. Valuing ecosystem services from wetlands restoration in the Mississippi Alluvial Valley. Ecol. Econ. 69, 1051-1061. http://dx.doi.org/10.1016/j.ecolecon.2009.11.022.

Kareiva, P., Tallis, H., Ricketts, T.H., Daily, G.C., Polasky, S., 2011. Natural Capital: Theory and Practice of Mapping Ecosystem Services. Oxford University Press.

Kessler, K., 2010. Analysis of nitrogen loading reductions for wastewater treatment facilities and non-point sources in the Great Bay Estuary watershed Appendix E: Capital and operational/maintenance costs associated with nitrogen removal at 18 municipal wastewater treatment facilities discharging to the Great Bay Estuary. NH Department of Environmental Services, Concord, NH.

Kinney, E.L., Valiela, I., 2011. Nitrogen loading to Great South Bay: Land use, sources, retention, and transport from land to bay. J. Coast. Res, 672-686. http://dx.doi. org/10.2112/Jcoastres-D-09-00098.1.

Krause, P., Boyle, D.P., Bäse, F., 2005. Comparison of different efficiency criteria for hydrological model assessment. Adv. Geosci. 5, 89-97.

Lee, K.-S., Short, F.T., Burdick, D.M., 2004. Development of a nutrient pollution indicator using the seagrass, Zostera marina, along nutrient gradients in three New England estuaries. Aquat. Bot. 78, 197-216.

Legates, D.R., McCabe, G.J., 1999. Evaluating the use of "goodness-of-fit" measures in hydrologic and hydroclimatic model validation. Water Resour. Res. 35, 233-241. http://dx.doi.org/10.1029/1998WR900018. 
Line, D.E., White, N.M., Osmond, D.L., Jennings, G.D., Mojonnier, C.B., 2002. Pollutant export from various land uses in the Upper Neuse River Basin. Water Environ. Res. 74, 100-108.

Liu, J., Dietz, T., Carpenter, S.R., Folke, C., Alberti, M., Redman, C.L., Schneider, S.H., Ostrom, E., Pell, A.N., Lubchenco, J., Taylor, W.W., Ouyang, Z., Deadman, P., Kratz, T., Provencher, W., 2007. Coupled Human and Natural Systems. Ambio 36, 639-649.

Loehr, R.C., 1974. Characteristics and Comparative Magnitude of Non-Point Sources. J. Water Pollut. Control Fed. 46, 1849-1872.

Loehr, R.C., Ryding, S.O., Sonzogni, W.C., 1989. Estimating the nutrient load to a waterbody, The Control of Eutrophication of Lakes and Reservoirs, Man and the Biosphere. Parthenon Publishing Group, London, UK, pp. 115-146.

Lowrance, R., Altier, L.S., Newbold, J.D., Schnabel, R.R., Groffman, P.M., Denver, J.M., Correll, D.L., Gilliam, J.W., Robinson, J.L., Brinsfield, R.B., et al., 1997. Water quality functions of riparian forest buffers in Chesapeake Bay watersheds. Environ. Manag. 21, 687-712.

Millennium Ecosystem Assessment, 2003. Ecosystems and Human Well-Being: A Framework for Assessment. Island Press, Washington, DC.

Mitsch, W.J., Day, J.W., Gilliam, J.W., Groffman, P.M., Hey, D.L., Randall, G.W., Wang, N., 2001. Reducing Nitrogen Loading to the Gulf of Mexico from the Mississippi River Basin: Strategies to Counter a Persistent Ecological Problem Ecotechnology - the use of natural ecosystems to solve environmental problems-should be a part of efforts to shrink the zone of hypoxia in the Gulf of Mexico. BioScience 51, 373-388.

Neßhöver, C., Timaeus, J., Wittmer, H., Krieg, A., Geamana, N., van den Hove, S., Young, J., Watt, A., 2013. Improving the science-policy interface of biodiversity research projects, GAIA - Ecol. Perspect. Sci. Soc. 22, 99-103.

Office of Research and Development, Office of Water, 2012. National Coastal Condition Report IV (No. EPA-842-R-10-003). United States Environmental Protection Agency, Washington, DC.

Odell, J., Eberhardt, A., Burdick, D.M., Ingraham, P., 2006. Great Bay Estuary restoration compendium. University of New Hampshire.

Piscataqua Region Estuaries Partnership, 2009. Environmental Indicators Report University of New Hampshire, Durham NH.

Piscataqua Region Estuaries Partnership, 2012. Final Environmental Data Report December 2012: Technical Support Document for the 2013 State of our Estuaries Report (Paper 265). PREP Publications.

Piscataqua Region Estuaries Partnership, 2013. The State of Our Estuaries. University of New Hampshire, Durham NH.

President's Council of Advisors on Science and Technology, 2011. Sustaining Environmental Capital: Protecting Society and the Economy (Report to the President). Executive Office of the President, Washington, DC.

Rast, W., Lee, G.F., 1978. Summary Analysis Of The North American (US Portion) OCED Eutrophication Project: Nutrient Loading - Lake Response Relationships And Trophic State Indices.

Reckhow, K., Beaulac, M., Simpson, J., 1980. Modeling Phosphorus Loading and Lake Response under Uncertainty: A Manual and Compilation of Export Coefficients. U.S. Environmental Protection Agency, East Lansing, Michigan.

Ribaudo, M.O., Heimlich, R., Peters, M., 2005. Nitrogen sources and Gulf hypoxia: potential for environmental credit trading. Ecol. Econ. 52, 159-168. http://dx doi.org/10.1016/j.ecolecon.2004.07.021.

Roy, A.H., Rhea, L.K., Mayer, A.L., Shuster, W.D., Beaulieu, J.J., Hopton, M.E., Morrison St., M.A., Amand, A., 2014. How Much Is Enough? Minimal Responses of Water Quality and Stream Biota to Partial Retrofit Stormwater Management in a Suburban Neighborhood. PLoS ONE 9. http://dx.doi.org/10.1371/journal. pone.0085011.

Ruckelshaus, M., McKenzie, E., Tallis, H., Guerry, A., Daily, G., Kareiva, P., Polasky, S., Ricketts, T., Bhagabati, N., Wood, S.A., Bernhardt, J., 2015. Notes from the field: lessons learned from using ecosystem service approaches to inform real-world decisions. Ecol. Econ. http://dx.doi.org/10.1016/j.ecolecon.2013.07.009.

Russi, D., ten Brink, P., Farmer, A., Badura, T., Coates, D., Förster, J., Kumar, R., Davidson, N., 2013. The economics of ecosystems and biodiversity for water and wetlands. IEEP.
Saunders, D.L., Kalff, J., 2001. Nitrogen retention in wetlands, lakes and rivers. Hydrobiologia 443, 205-212. http://dx.doi.org/10.1023/A:1017506914063.

Sharp, R., Tallis, H., Ricketts, T., Guerry, A., Wood, S.A., Chaplin-Kramer, R., Nelson, E. Ennaanay, D., Wolny, S., Olwero, N., Vigerstol, K.L., Pennington, D., Mendoza, G., Aukema, J.E., Foster, J., Forrest, J., Cameron, D., Arkema, K., Lonsdorf, E., Kennedy, C., Vertutes, G., Kim, C.K., Guannel, G., Papenfus, M., Toft, J., Marsik, M., Bernhardt, J., Griffin, R., Glowinski, K., Chaumont, N., Perelman, A., Lacayo, M., Mandle, L., Hamel, P., Vogl, A., 2014. InVEST User's Guide.

Smart, S.M., Pearce-Higgins, J.P., Wright, L., Comber, A.J., Howard, D.C., Maskell, L.., Jones, M.L.M., 2012. Exploring the Future: Phase 1 - scoping Current and Future Use of Spatial Decision Support Tools (sDST) for integrated planning for LandUse, Biodiversity and Ecosystem Services across England (Final Report to Defra)

Soil Survey Staff, Natural Resources Conservation Service, United States Department of Agriculture, 2013. Web Soil Survey [WWW Document]. URL $\langle$ http://websoil survey.sc.egov.usda.gov/App/HomePage.htm $\rangle$ (accessed 2.5.14).

Spalding, C., 2012. EPA Overreach and the impact on New Hampshire Communities: Testimony of C. Spalding Region 1 Administrator, US Environmental Protection Agency. U.S. Government Printing Office,, Washington, DC.

Swetnam, R.D., Fisher, B., Mbilinyi, B.P., Munishi, P.K.T., Willcock, S., Ricketts, T., Mwakalila, S., Balmford, A., Burgess, N.D., Marshall, A.R., Lewis, S.L., 2011. Mapping socio-economic scenarios of land cover change: a GIS method to enable ecosystem service modelling. J. Environ. Manag. 92, 563-574. http://dx. doi.org/10.1016/j.jenvman.2010.09.007.

Talberth, J., Gray, E., Yonavjak, L., Gartner, T., 2013. Green versus Gray: nature's solutions to infrastructure demands 4.

Trabucco, A., Zomer, R.J., 2009. Global aridity index (global-aridity) and globa potential evapo-transpiration (Global-PET) geospatial. Database.

Trowbridge, P., Wood, M.A., Underhill, J.T., Healy, D.S., 2014. Great Bay Nitrogen Non-Point Source Study. NH Department of Environmental Services, Concord, $\mathrm{NH}$

United States Geological Survey, United States Department of Agriculture- Natura Resources Conservation Service, Environmental Protection Agency, 2013. Watershed Boundary Dataset.

USEPA, 1983. Results from the Nationwide Urban Runoff Program (Volume 1 - Final Report No. 5927A). Water Planning Division, Washington, DC.

Vanasse Hangen Brustlin, Inc., 2014. Oyster River integrated watershed plan for nitrogen load reductions: Final technical report (No. ORIWMP-v12-Final). Town of Durham, University of New Hampshire, Durham NH.

Vigerstol, K.L., Aukema, J.E., 2011. A comparison of tools for modeling freshwater ecosystem services. J. Environ. Manag. 92, 2403-2409.

Villa, F., Bagstad, K.J., Voigt, B., Johnson, G.W., Portela, R., Honzák, M., Batker, D., 2014. A Methodology for adaptable and robust ecosystem services assessment PLoS One 9, e91001. http://dx.doi.org/10.1371/journal.pone.0091001.

Vitousek, P.M., Aber, J.D., Howarth, R.W., Likens, G.E., Matson, P.A., Schindler, D.W. Schlesinger, W.H., Tilman, D.G., 1997. Human alteration of the global nitrogen cycle: sources and consequences. Ecol. Appl. 7, 737-750.

Washburn, E.L., 2013. A social landscape analysis of land use decision making in a coastal watershed. Soc. Nat. Resour. 26, 325-338. http://dx.doi.org/10.1080/ 08941920.2012.700762.

Willmott, C.J., 1982. Some comments on the evaluation of model performance. Bull. Am. Meteorol. Soc. 63, 1309-1313. http://dx.doi.org/10.1175/1520-0477(1982) $063<1309$ :SCOTEO > 2.0.CO;2.

Wollheim, W.M., Peterson, B.J., Thomas, S.M., Hopkinson, C.H., Vörösmarty, C.J., 2008. Dynamics of $\mathrm{N}$ removal over annual time periods in a suburban river network. J. Geophys. Res. Biogeosci. 113, G03038. http://dx.doi.org/10.1029/ 2007JG000660.

Xu, X., Liu, W., Scanlon, B.R., Zhang, L., Pan, M., 2013. Local and global factors controlling water-energy balances within the Budyko framework. Geophys. Res. Lett. 40. http://dx.doi.org/10.1002/2013GL058324.

Zhang, L., Hickel, K., Dawes, W.R., Chiew, F.H., Western, A.W., Briggs, P.R., 2004. A rational function approach for estimating mean annual evapotranspiration. Water Resour. Res., 40. 